status; law of property; law of wrongs and injuries; law of contract and transactions; conception of status, responsibility and liability; scope and methods of research. It is intended to publish the papers presented at the seminar, with an introductory survey based on the discussions.

\title{
World Conference on the Clash of Colour
}

A world conference on problems of race and the clash of colour was held in Copenhagen from 5 to I $2_{2}$ September 1965 , under the sponsorship of the Congress for Cultural Freedom and the American Academy of Arts and Sciences. Some thirty-five scholars and experts on race relations from the United States, Latin America, Japan, Ceylon, Sweden, France, and Great Britain met under the joint chairmanship of Professor Georges Balandier, of the Ecole Pratique des Hautes Études, and Mr. Philip Mason, Director of the Institute of Race Relations, London.

The results of the meeting will be collected in a special issue of the quarterly magazine Daedalus, published at Harvard University.

\section{Centre of Ethno-Pastoral Studies, Banningville, Congo/Léo}

THE Centre of Ethno-Pastoral Studies of the Society of the Divine Word, which is associated with the Anthropos Institute, held its first Study Week at St. Paul's College (B.P. I9, Banningville) from 23 to 28 August 1965 . The organizer and chairman was Father Hermann Hochegger SVD, and problems of traditional forms of marriage, family life, clan systems, and education were discussed. It is hoped to publish the results of this conference in the near future, and to arrange another study week in 1966 on the subject of the idea of God, and belief in spirits other than those of the ancestors.

\section{Ahmadu Bello University: Department of Languages}

The Department of Languages of Ahmadu Bello University has been engaged on the following projects: Hausa studies, including the expansion and revision of Mr. KirkGreene's draft research memoranda on Hausa names, titles and Sarautu, and place-names; compilation of specialized word-lists, ancient and modern, with regard to clothing and dress, food and cooking, war and weapons, and pre-1900 emirate government and administration; and a symposium on the identification, characteristics, and location of Hausa dialects, both horizontally through ethnic geography and vertically through social status and educational achievement. The department is also compiling a comprehensive 5,000 words English-Fulani vocabulary in the Adamawa dialect, and preparing vocabularies of current political, parliamentary, administrative, and international terms in Kanuri, Tiv, and Nupe. Work is also proceeding on a 'Six Language Basic Vocabulary for Nigeria', comprising, English, French Hausa, Yoruba, Ibo, and Fulani, consisting of some 2,000 common words in each language.

\section{APA Annual Convention in Chicago}

A Symposium on Social Psychological Research in Developing Countries was held at the APA Annual Convention in Chicago in September 1965 , under the chairmanship of Henri Tajfel of the University of Oxford. Dr. Donald T. Campbell of Northwestern University was the Discussant and the following papers were presented:

Henri Tajfel (Oxford)

International co-operation in social psychology: some problems and possibilities. 